Acta vet. scand. $1976,17,451-457$.

From the Research Station of the Veterinary Institute, Skara, Sweden.

\title{
STUDIES OF TRANSFERRIN POLYMORPHISM IN SWEDISH CATTLE USING AGAROSE GEL ELECTROPHORESIS*
}

\author{
By \\ Per Liberg and Gunnar Carlström
}

\begin{abstract}
LIBERG, PER and GUNNAR CARLSTRÖM: Studies of transferrin polymorphism in Swedish cattle using agarose gel electrophoresis. Acta vet. scand. $1976,17,451-457$. - The polymorphic transferrin picture in the sera from 894 Swedish cattle was investigated with an agarose gel electrophoresis technique. The serum transferrin bands in the electrophoresis pattern were first identified by labelling with ${ }^{59} \mathrm{Fe}$. Six existing phenotypes based on the alleles $T f^{A}, T f^{D}$ and $T f^{E}$ could be detected. The frequencies of transferrin types and transferrin alleles are presented, and it is concluded that there are great differences in the frequencies between the Swedish Red and White and the Swedish Friesian.
\end{abstract}

transferrin polymorphism; cattle; agarosegel electrophoresis.

Transferrin, an iron-binding and iron-transferring serum protein, was discovered by Holmberg \& Laurell (1945) and Schade \& Caroline (1946). The physiological significance of transferrin for absorption, transfer and deposition was pointed out by Laurell (1952).

Smithies $(1957,1958)$ studied the polymorphism of human $\beta_{1}$-globulin by starch electrophoresis. Autoradiographic studies with ${ }^{59} \mathrm{Fe}$ showed that the polymorphic $\beta$-globulin was transferrin and that the variable $\beta_{1}$-globulins represented different molecular species of serum transferrin (Giblett et al. 1959). Starch gel electrophoresis and autoradiography have since been the most used methods for the study of transferrin variations.

Starch gel electrophoresis showed six $\beta$-globulin phenotypes in cattle. These are called AA, DD, EE, AD, DE and AE according to the occurrence in individual sera of three electrophoretically different $\beta$-globulin fractions, denoted A, D, E according to

* The investigations were supported by the Swedish Council for Forestry and Agricultural Research. 
diminishing anodal mobility. Each fraction proved to consist of three to five detectable zones. In heterozygotes these zones partially coincide. Familial and population data supported the theory that the observed polymorphism is controlled by three allelic genes without dominant character (Ashton 1958, Smithies \& Hickman 1958). In accordance with these findings the following allelic symbols were chosen: $\mathrm{Tf}^{\mathrm{A}}, \mathrm{Tf}^{\mathrm{D}}, \mathrm{Tf}^{\mathrm{E}}$. The mode of inheritance has been confirmed in several studies of European and American cattle breeds, in which significant differences in frequency of alleles between breeds have also been observed (Gahne et al. 1960, Gall \& Berg 1964, Datta et al. 1965, and others).

New alleles have later been reported. Up to now some 10 transferrin alleles have been discovered in different breeds, several of which have been observed only in Zebu cattle. Improved starch gel electrophoresis technique revealed that $\mathrm{Tf}^{\mathrm{D}}$ allele occurring in European, among other breeds, actually consists of two alleles, $\mathrm{Tf}^{\mathrm{D}} \mathbf{1}$ and $\mathrm{Tf}^{\mathrm{D}} \mathbf{2}$, of which $\mathrm{Tf}^{\mathrm{D}} \mathbf{1}$ gives rise to transferrin fractions with rather greater mobility than TfD2 (Jamieson 1965, Kristjansson \& Hickman 1965, Ashton 1965).

Brummerstedt-Hansen (1962) showed that the different transferrin components in cattle are immunologically identical. Abe et al. (1974) determined transferrin phenotypes in Holstein cattle and correlated the phenotype to the serum transferrin concentration, but found no significant correlation between them.

The various molecular variants in a protein system are controlled by genes in a chromosomal locus. Transferrin has been successfully used as marker locus in parentage investigations (Gahne 1961, Brummerstedt-Hansen et al. 1963, Jamieson), in twin diagnosis (Gahne, Datta \& Stone 1963, Hesselholt et al. 1965), and in gene frequency studies. Studies of breed structure in cattle have been made with the use of the haemoglobin and transf errin systems.

The selective value of the serum allele types could have practical application in breeding or explain the mechanism through which polymorphism is maintained. Studies of the selective value of the significance of the bovine transferrin locus for, inter alia, milk production and fertility have shown contradictory results (Ashton 1960, 1965, Larsen 1961, Rausch et al. 1963, Datta et al., Meyer 1967).

Transferrin is the only plasma protein which can bind iron with very high association constant and thus prevent the oc- 
currence of free iron ions. Transferrin binds iron so rigidly that it has a bacteriostatic effect by depriving the bacteria of the iron needed for growth (Schade 1963, Fletcher 1971, Bullen et al. 1972).

The different transf errin variants have so far been considered to lack clinical interest, as the iron-binding capacity of the molecule is unaffected by the underlying amino acid substitutions. Possibly, however, other metals as well can be bound to transferrin. Studies have shown that several metals, such as Ca and $\mathrm{Pb}$, can be bound to all electrophoretically demonstrable serum protein fractions. Pfordte \& Ponsold (1971) showed, in the rat, that $\mathrm{Ca}$, for example, is bound both by albumin and $\alpha_{1}^{-}, \alpha_{2}-, \beta-$ and $\gamma$-globulin, $\beta$-globulin having the greatest molar binding capacity for $\mathrm{Ca}$ and albumin the smallest.

The object of the present study was to illustrate the use of the agarose gel electrophoresis technique for determination of different transferrin phenotypes and to obtain fresh data of their frequency of distribution in Swedish cows.

\section{MATERIAL AND METHODS}

The material consisted of 894 cattle, chiefly dairy cows. Of this number, $465(52 \%)$ were Swedish Red and White (SRB) and $153(17 \%)$ Swedish Friesian (SLB). The remainder were of other breeds, crossbreeds, or of unknown breed. The material was collected for the most part in Skaraborg County.

Serum samples were investigated by a modified agarose gel electrophoresis technique ad modum Carlström \& Liberg (1975). This method provides good possibilities of assessing the polymorphic transferrin picture of bovine sera. Six existing phenotypes based on the alleles $\operatorname{Tf}^{\mathrm{A}}, \mathrm{Tf}^{\mathrm{D}}$ and $\mathrm{Tf}^{\mathrm{E}}$ could be detected in the electrophoresis pattern. No attempt was made to divide $\mathbf{T f}^{\mathrm{D}}$ into two alleles, $\operatorname{Tf}^{\mathrm{D}} \mathbf{1}$ and $\mathrm{Tf}^{\mathrm{D}} \mathbf{2}$.

For identification of serum transferrin in the electrophoresis pattern some sera were labelled with ${ }^{59} \mathrm{Fe}\left(3 \mu \mathrm{Ci}{ }^{59} \mathrm{Fe} / \mathrm{ml}\right.$ serum $)$. Serum containing ${ }^{59} \mathrm{Fe}$-labelled transferrin was separated electrophoretically and the fixed electrophoresis pattern was left to blacken an X-ray film for $\mathbf{1 0}$ days. Identification was then done by direct positional comparison between the stained protein pattern and the autoradiogram. The autoradiogram in Fig. 1 shows five of the six transferrin phenotypes. 

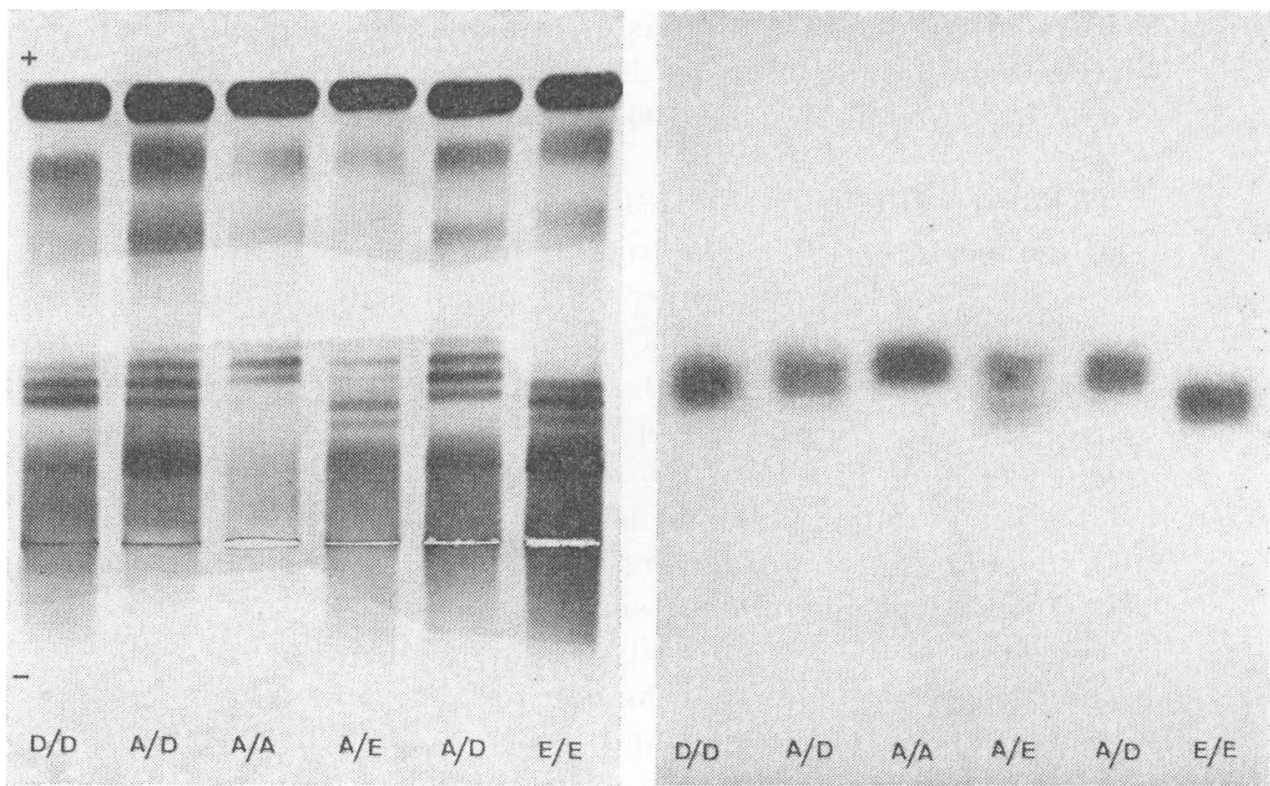

Figure 1. Identification of serum transferrin by direct positional comparison between the stained electrophoretic protein pattern (to the left) and the autoradiogram of transferrin labelled with ${ }^{59} \mathrm{Fe}$ (to the right). The autoradiogram shows five of the six transferrin phenotypes studied.

\section{RESULTS AND DISCUSSION}

The frequencies of phenotypes in the breeds studied are shown in Table 1. Gahne (1961) investigated the frequencies of alleles of different transferrin types in the chief dairy cattle breeds in Sweden. The frequencies of alleles in the present material are shown in Table 2.

Table 1. The frequencies of transferrin types in Swedish cattle.

\begin{tabular}{lccccccc} 
Breed & $\begin{array}{c}\text { Number } \\
\text { of } \\
\text { animals }\end{array}$ & TfA/TfA & TfA/Tf & TfA/TfE & TfD/TfD & TfD/TfE & TfE/TfE \\
\hline SRB & 465 & 0.30 & 0.16 & 0.33 & 0.04 & 0.08 & 0.09 \\
SLB & 153 & 0.12 & 0.36 & 0.14 & 0.30 & 0.05 & 0.03 \\
Others & 276 & 0.22 & 0.29 & 0.24 & 0.12 & 0.09 & 0.04 \\
\hline Total & 894 & 0.25 & 0.23 & 0.27 & 0.11 & 0.08 & 0.06 \\
\hline
\end{tabular}


Table 2. The frequencies of transferrin alleles in Swedish cattle.

\begin{tabular}{lcccc}
\hline Breed & $\begin{array}{c}\text { Number of } \\
\text { animals }\end{array}$ & TfA & TfD & TfE \\
\hline SRB & 465 & 0.55 & 0.16 & 0.29 \\
SLB & 153 & 0.37 & 0.51 & 0.12 \\
Others & 276 & 0.48 & 0.31 & 0.21 \\
\hline Total & 894 & 0.49 & 0.27 & 0.24 \\
\hline
\end{tabular}

As will be seen, SRB differs markedly from SLB, having a greatly higher frequency of $\mathrm{Tf}^{\mathrm{E}}$ and greatly lower frequency of $T^{D}{ }^{D}$. The present figures for SRB are closely similar to the results of Ghane, while those for SLB show a considerably higher frequency of $\mathbf{T f}^{\mathrm{E}}$ and correspondingly lower frequency of $\mathbf{T f}^{\mathrm{A}}$ than reported by Ghane. Whereas Gahne found no $\mathrm{Tf}^{\mathrm{E}} / \mathrm{Tf}^{\mathrm{E}}$ animals among his SLB cows, there were four such cows in the present study. The interval of 10-15 years between the two studies, with intensive breeding and increased crossbreeding, has probably contributed to the fairly large discrepancy in frequencies of alleles for SLB. SRB is a national breed which over a long period has received no decisive new gene material from outside. SLB, on the other hand, is an international breed which has received some new gene material from different quarters. In the last decade, moreover, grading up of SRB to SLB has taken place.

The results are being used in a new study to compare the frequency of phenotypes in a paresis material (cows with parturient paresis and cows with known disposition for the disease) with the, in this respect, normal population in the present study.

\section{REFERENCES}

Abe, T., T. Oishi \& M. Kanemaki: Transferrin genotypes and their relationship with serum transferrin levels in cattle. Bull. nat. Inst. Anim. Ind. 1974, 28, 1-6.

Ashton, G. G.: Genetics of $\beta$-globulin polymorphism in British cattle. Nature (Lond.) 1958, 182, 370-372.

Ashton, G. C.: $\beta$-globulin polymorphism and economic factors in dairy cattle. J. agric. Sci. 1960, 54, 321-328.

Ashton, G. C.: Cattle serum transferrin: A balanced polymorphism. Genetics 1965, 51, 431-437.

Brummerstedt-Hansen, E.: Immunological conditions of transferrin types in cattle. Acta vet. scand. 1962, 3, 245—255. 
Brummerstedt-Hansen, E., J. Moustgaard \& I. Mфller: Serum transferrinpolymorphism in Danish cattle breeds. Aarsskr. kgl. Vet.og Landbohøjsk. 1963, 13-26.

Bullen, J. J., H. Rogers \& L. Leigh: Ironbinding proteins in milk and resistance to Escherichia coli infection in infants. Brit. med. J. $1972,1,69-75$.

Carlström, G. \& P. Liberg: Agarose gel electrophoretic separation of blood serum proteins in cattle. Acta vet. scand. 1975, 16, 520524.

Datta, S. P. \& W. H. Stone: Transferrin of cattle twins. Proc. Soc. exp. Biol. (N.Y.) 1963, 113, 756-759.

Datta, S. P., W. H. Stone, W. J. Tyler \& M. R. Irwin: Cattle transferrins and their relation to fertility and milk production. J. Anim. Sci. 1965, 24, 313-318.

Fletcher, J.: The effect of iron and transferrin on the killing of Escherichia coli in fresh serum. Immunology 1971, 20, 493-500.

Gahne, B.: Studies of transferrins in serum and milk of Swedish cattle. Anim. Prod. 1961, 3, 135-145.

Gahne, B., J. Rendel \& O. Venge: Inheritance of B-globulins in serum and milk from cattle. Nature (Lond.) 1960, 186, 907-9.08.

Gall, G. A. E. \& R. T. Berg: Studies of the inheritance of bovine serum transferrins. Anim. Prod. 1964, 6, 107-118.

Giblett, E. R., C. G. Hickman \& O. Smithies: Serum transferrins. Nature (Lond.) 1959, 183, 1589-1590.

Hesselholt, M., B. Larsen, P. B. Nielsen \& B. Palludan: Studies on blood groups in cattle, horses and pigs. Blood groups of animals. 9. Europ. Anim. Blood Grp. Conf., Proc., Prague 1965, 4961.

Holmberg, C. G. \& C. B. Laurell: Studies on the capacity of serum to bind iron. A contribution to our knowledge of the regulation mechanism of serum iron. Acta physiol. scand. 1945, 10, 307319.

Jamieson, A.: The genetics of transferrin in cattle. Heredity 1965, 20, $419-441$.

Kristjansson, F. K. \& C. G. Hickman: Subdivision of TfD for transferrins in Holstein and Ayrshire cattle. Genetics 1965, 52, 627630.

Larsen, $H$.: Investigations concerning the possible influence of serum$\beta$-globulins, hemoglobins and $\beta$-lactoglobulins upon yielding ability of cattle. Kgl. Vet.- og Landboh $\varnothing$ jsk., Inst. Sterilitetsforskn. Aarsberetn. Copenhagen 1961, 125-134.

Laurell, C.-B.: Plasma iron and the transport of iron in the organism. Pharmacol. Rev. 1952, 4, 371-395.

Meyer, H.: Untersuchungen zum Transferrinpolymorphismus beim Rind. (Studies on transferrin polymorphism in cattle). Zbl. Vet.-Med. Reihe A 1967, 14, 335-347.

Pfordte, K. \& W. Ponsold: Über die Calcium/Serumprotein-Bindung. (On the binding between calcium and serum proteins). Endokrinologie 1971, 57, 230-236. 
Rausch, W. H., T. M. Ludwick, D. F. Weseli, D. O. Richardson, E. R. Rader, E. W. Brum, H. C. Hines, A. K. Towler \& D. Plowman: Association of bovine transferrin types, as determined by disc electrophoresis, with fertility and production. J. Dairy Sci. $1963,46,648$.

Shade, A. L.: Significance of serum iron for the growth, biological characteristics and metabolism of Staphylococcus aureus. Biochem. Z. 1963, 338, 140-148.

Shade, A. L. \& L. Caroline: An iron-binding component in human blood plasma. Science 1946, 104, 340-341.

Smithies, O.: Variations in human serum $\beta$-globulins. Nature (Lond.) $1957,180,1482-1483$.

Smithies, O.: Third allele at the serum $\beta$-globulin locus in humans. Nature (Lond.) 1958, 181, 1203-1204.

Smithies, $O . \&$ C. G. Hickman: Inherited variations in the serum proteins of cattle. Genetics $1958,43,374-385$.

\section{SAMMANFATTNING}

Undersökning av transferrinpolymorfismen hos nötkreatur med agarosgel-elektrofores.

Den polymorfa transferrin-bilden i serum undersöktes hos 894 nötkreatur med agaros-gel-elektrofores. De flerfaldiga transferrinbanden i elektroforesmönstret identifierades först genom märkning med den radioaktiva isotopen ${ }^{59} \mathrm{Fe}$. Sex fenotyper baserade på allelerna TfA, TfD och TfE kunne bestämmas. Frekvenserna transferrin-typer och transferrin-alleler presenteras varvid framgår att det föreligger relativt stora skillnader $i$ frekvenserna mellan SRB och SLB.

(Received September 30, 1976).

Reprints may be requested from: Per Liberg, the Research Station of the Veterinary Institute, Box 180, S-53200 Skara, Sweden. 